\title{
Effects of agricultural land use on dissolved organic carbon and nitrogen in surface runoff and subsurface drainage
}

\section{Manninen, Noora Johanna}

2018-03-15

Manninen, N J , Soinne , H S , Lemola , R, Hoikkala , L K \& Turtola , E 2018 , ' Effects of agricultural land use on dissolved organic carbon and nitrogen in surface runoff and subsurface drainage ' , The Science of the Total Environment , vol. 618 , pp. 1519-1528 . https://doi.org/10.1016/j.sc

http://hdl.handle.net/10138/237874

https://doi.org/10.1016/j.scitotenv.2017.09.319

acceptedVersion

Downloaded from Helda, University of Helsinki institutional repository.

This is an electronic reprint of the original article.

This reprint may differ from the original in pagination and typographic detail.

Please cite the original version. 
Effects of agricultural land use on dissolved organic carbon and nitrogen in surface runoff and subsurface drainage

Noora Manninen ${ }^{\mathrm{a},}$, , Helena Soinne ${ }^{\mathrm{a}}$, Riitta Lemola ${ }^{\mathrm{b}}$, Laura Hoikkala ${ }^{\mathrm{c}, \mathrm{d}}$, Eila Turtola ${ }^{\mathrm{b}}$

aUniversity of Helsinki, Environmental soil science, P.O. Box 56, FI-00014 University of Helsinki, Finland

${ }^{b}$ Natural resources institute Finland, Humppilantie, Fl-31600 Jokioinen, Finland

'University of Helsinki, P.O. Box 65, FI-00014 University of Helsinki, Finland

${ }^{\mathrm{d}}$ Marine Research Centre, Finnish Environment Institute, Erik Palménin aukio 1, P.O.Box 140, Fl-00251

Helsinki, Finland

*Corresponding author. University of Helsinki, Environmental soil science, P.O. Box 56, Fl-00014 University of Helsinki, Finland.

E-mail address: noora.manninen@helsinki.fi (N. J. Manninen).

\section{Abstract}

Dissolved organic carbon (DOC) load in discharges from cultivated soils may have negative impacts on surface waters. The magnitude of the load may vary according to soil properties or agricultural management practices. This study quantifies the DOC load of cereal cultivated mineral soils and investigates whether the load is affected by agricultural practices. Discharge volumes and concentrations of DOC and dissolved organic nitrogen (DON) were continually measured at three sites from surface runoff and artificial subsurface drainage or from combined total discharge over a two-year period (2012-2014). Two experimental sites in South-West Finland had clayey soils (with soil carbon contents of $2.7-5.9 \%$ in the topmost soil layer), and the third site in West-Central Finland had sandy soil (soil carbon contents of 4.36.2\%). Permanent grassland, organic manure application, mineral fertilization, and conventional ploughing or no-till activities were studied. Furthermore, the biodegradable DOC pool of surface runoff and subsurface drainage water from no-till and ploughed fields was estimated in a 2-month incubation experiment with typical bacteria communities collected from the Baltic Sea seawater.

The annual DOC and DON loads were affected by discharge volume and seasonal weather conditions. The loads varied between 25-52 kg ha-1 and 0.8-3.2 $\mathrm{kg} \mathrm{ha}^{-1}$, respectively, and were comparable to those from boreal forests with similar soil types. The DOC load increased with increasing topsoil carbon content at all sites. There were slightly higher DOC concentrations and DOC load from permanent grassland, but otherwise we could not distinguish any clear management-induced differences in the total DOC loads. 
While only $6-17 \%$ of the DOC in discharge water was biologically degraded during the 2-month incubation, the proportion of biodegradable (labile) DOC in surface runoff appeared to increase when soil was ploughed compared to no-till.

\section{Graphical abstract}

\section{Highlights}

\section{Keywords}

Agricultural management; Biodegradation; Discharge route; DOC; DON; SOM

\section{Introduction}

Soil organic matter (SOM) has many important functions in agricultural soils, e.g. it increases soil water holding capacity, improves soil structure and provides nutrients for plants. However, a declining trend in the organic carbon $(\mathrm{OC})$ content in Finnish agricultural soils has been detected by a long-term monitoring study conducted by Heikkinen et al. (2013). OC is lost from soil as $\mathrm{CO}_{2}$ due to microbial decomposition of SOM. It may also be carried by the runoff water when adsorbed to soil particles or, as dissolved organic carbon (DOC).

The loss of OC from soil may have implications for both boreal agriculture and the inland or sea water quality. Leaching of DOC with runoff water may increase the risk of eutrophication in the receiving waters. Increased DOC concentrations in surface waters have been reported across Europe and North America (Evans et al., 2005; Lepistö et al., 2008). In the Baltic Sea water, Fleming-Lehtinen et al. (2015) found an increasing trend of total organic carbon (TOC) concentrations along the west coast of Finland up to North of the Bothnian Bay (latitudes between c. $59^{\circ} \mathrm{N}$ and $65^{\circ} \mathrm{N}$ ) and to the East of the Southern Gulf of Finland (longitudes between c. $20^{\circ} \mathrm{E}$ and $28^{\circ} \mathrm{E}$ ). Coastline sea water TOC concentrations varied between 3 and 6 $\mathrm{mg}^{-1}$ during the 30 year study, and the findings of isotope studies indicated the TOC to be of terrestrial origin. The increase was consistent with the increase in riverine TOC concentrations, which were measured at up to fourfold compared to the concentrations measured in the seawater (Fleming-Lehtinen et al., 2015). The proportion of DOC in TOC in Finnish river systems is more than $90 \%$ (Mattsson et al., 2005) and thus, TOC concentrations are comparable with DOC concentrations.

Terrestrial DOC and labile DON inputs can provide an important energy source for heterotrophic bacteria (Berg et al., 2001; Korth et al., 2011), and therefore dissolved organic matter may enhance eutrophication 
of coastal waters due to phytoplankton growth. In the Baltic Sea, where riverine inputs of DOC are high, 2 to $18 \%$ of DOC can be degraded by heterotrophic bacteria within weeks or months (Hoikkala et al., 2012; Asmala et al., 2013; Hulatt et al., 2014; Autio et al., 2016). Means of $40 \%$ of the total nitrogen and $20 \%$ of the total phosphorus in the nutrient load that enters to the Baltic Sea are in organic form during the summer season (Stepanauskas et al., 2002). The percentages of DON and dissolved organic $P$ that were labile for bacteria (within 2 weeks) were $25 \%$ and $30 \%$ of the total bioavailable nutrients, respectively (Stepanauskas et al., 2002). Riverine loads of dissolved organic nutrients also support the growth of autotrophs in the Baltic Sea (Jurgensone \& Aigars, 2012; Purina et al., 2004).

The DOC in river water is a highly discharge-dependent variable (Räike et al., 2012; Fraser et al., 2001; Strohmeier et al., 2013) and the amount of DOC that enters the surface waters, as well as its timing, are controlled by seasonal, meteorological and hydrological events such as temperature, storms and springtime snowmelt (Sinsabaugh and Findlay, 2003). The spring season in Finland is short but it may contribute to as much as half of the annual discharge and leaching of DOC from headwater catchments (Kortelainen et al., 1997). Mattsson et al. (2009) reported that DOC concentrations correlate negatively with the annual mean air temperature and precipitation, in addition to the amount of annual discharge.

On the catchment scale, DOC concentrations in river water and DOC load are positively correlated with the proportion of peatlands (Histosols, IUSS Working Group WRB, 2015) (Laudon et al., 2004; Mattsson et al., 2005). The data for agricultural soils is limited but some studies have reported increased DOC concentrations in river waters when the proportion of agricultural land is high in the catchment area (Mattsson et al., 2005). Larger annual fluctuations in soil moisture and temperature compared to forest soils have been suggested to increase the SOM solubility in the agricultural soil (Don and Schultze, 2008) and intensive tillage may increase the release of DOC as the result of enhanced mineralization of SOM (Kalbitz et al., 2000). Different agricultural practices may further affect the DOC load of cultivated soils. McTiernan et al. (2001) reported a high DOC load from agricultural grasslands and suggested it to be originated from the increased biomass production that resulted from $\mathrm{N}$ fertilization. Inputs of organic matter by animal manure may also result in higher water-extractable $\mathrm{OC}$ in soil thus increasing the potential for DOC loss. Intensive tillage may increase OC mineralization and DOC release, whereas no tillage (no-till) is known to increase OC content of the soil surface (Muukkonen et al., 2009; Havlin et al., 1989; Langdale et al., 1992; Van Eerd et al., 2014). Surface runoff flowing over the organic rich topsoil can be an important contributor to DOC in streams (Hornberger et al., 1994 and Mulholland, 1997), and the enrichment of $O C$ in the surface soil may lead to increased DOC concentration in surface runoff water. 
The principal aim of this study was to quantify the DOC loads exported from boreal cultivated mineral soils and to estimate the biodegradability of DOC in the marine environment. The secondary aim was to find out whether the DOC export is affected by such commonly variable agricultural practices as the tillage methods or the crop rotations. We used data from long-term experimental plots at three established research sites (Kotkanoja, Yöni and Toholampi) to test our hypotheses that 1 ) the DOC loads from cultivated mineral soils depend on the $\mathrm{OC}$ content of the topsoil, and 2) that higher DOC loads are exported from no-till plots compared to ploughed plots, and from organic manure application treated plots compared to mineral fertilization plots due to differences in SOM accumulation and inputs of manure, respectively.

\section{Materials and methods}

\subsection{Experimental fields}

Three mineral soil sites, where long-term crop rotations had been carried out by the Natural Resources Institute Finland (Luke), were chosen as the study sites. Two of these, Kotkanoja and Yöni, were Vertic Stagnosols (Lilja et al., 2017; IUSS Working Group WRB, 2015) and the third site, Toholampi, was Gleyic Podzol (Yli-Halla et al., 2000; IUSS Working Group WRB, 1998). Agricultural practices of conventional ploughing or no-till activities under spring cereal cultivation (in Kotkanoja), permanent grassland (in Yöni), and organic manure application or mineral fertilization under cereal cultivation (in Yöni and Toholampi) were studied. Detailed description of the farming practices on each experimental site can be found in supplementary material (Table S1). Two of the sites were located in Jokioinen $\left(60^{\circ} 49^{\prime} \mathrm{N}, 23^{\circ} 28^{\prime} \mathrm{E}\right)$ research station in South-West Finland, and are hereafter referred to as Kotkanoja and Yöni. The third site was in the region of Ostrobothnia in North-West Finland in Toholampi $\left(63^{\circ} 49^{\prime} \mathrm{N}, 24^{\circ} 09^{\prime} \mathrm{E}\right)$.

The DOC and DON concentrations were measured continually for two study years on the three experimental sites. Both sites of Kotkanoja and Yöni had soil clay content over $60 \%$ and topsoil mean C content, analyzed by dry combustion from air-dried and grounded soil sample with Vario Max $\mathrm{CN}$-analyzer, of $3.4 \%$ and $5.4 \%$, respectively. Soil $\mathrm{pH}$, measured in $0.01 \mathrm{M} \mathrm{CaCl}_{2}$ solution, varied between 5.5-5.8 at Kotkanoja and 4.7-5.9 at Yöni. The third site Toholampi had a sandy soil with topsoil mean C content of $5.0 \%$ and $\mathrm{pH}\left(\mathrm{CaCl}_{2}\right)$ of 5.4-5.8. The total $\mathrm{C}$ content of the soils is considered to be in organic form due to very low carbonate content in Finnish soils and thus, represents OC. All the experimental fields in this study had low OC\% below $20 \mathrm{~cm}$ depth. The detailed carbon content of separately studied 14 plots, including two replicates for the 7 different agricultural managements, on the three study sites are presented in Table 1. 
At the clayey Kotkanoja site, the experiment field was under spring cereal cultivation and divided into 4 plots of which two replicate plots represented no-till farming with direct sowing, and two plots represented conventional autumn-ploughing. These tillage treatments had been continually carried out since 2008. Even before that, the plots under no-till had not been ploughed since the autumn of 1991 but had been tilled to a shallow depth of less than $10 \mathrm{~cm}$, whereas the other two plots had a ploughing history (Turtola et al., 2007). In the no-till plots, soil was not tilled after harvest in autumn and seedbed was not separately prepared in spring before sowing. In the ploughed plots, conventional ploughing to $21 \mathrm{~cm}$ depth was done in the autumn after the harvest, and in the spring the seedbed was prepared by harrowing before the sowing. In the first study year (2012) the soil was very wet and ploughing could not be performed until November, but during the second study year in 2013 the plots were ploughed in September. All plots were sown and fertilized in both years in spring using the same variety of spring barley (Hordeum vulgare L.) and same rate of inorganic fertilizer (Table S1). All experimental plots were treated with glyphosate and herbicides when necessary (Table S1).

The clayey Yöni site had six experimental plots with three crop rotations including cereal cultivation as follows: 1) organic farming with manure (cattle slurry) application or 2) conventional farming with mineral fertilizers, and 3) permanent grassland. No mineral fertilization, herbicides or other pesticides were applied in organic management contrary to the conventional one. These managements had been carried on since 1995 and, except for the permanent grass, they included 5-year crop rotations of 2-year grass, rye (Secale cereale L.), mixture of oat (Avena sativa L.) and pea (Pisum sativum L.), and barley undersown with grass and clover (Trifolium pratense L.). Since 2012, cattle slurry was applied in three separate applications during the 5-year rotations: 1) One application in the same year with barley when grass was sown, 2) one application during the years of second grass harvest, and 3) one application during the year when rye was sown. In 2012 at the beginning of the first study year, the plots treated with manure and mineral fertilizers were under ley, which comprised a mixture of timothy (Phleum pratense L.), meadow fescue (Festuca pratensis Huds.) and red clover that was ploughed after cutting in late summer. Cattle slurry (c. $17 \mathrm{t} \mathrm{ha}^{-1}$ ) was then spread onto organic plots before ploughing both organic and conventional plots to the depth of $15 \mathrm{~cm}$ and sowing winter rye. Winter rye was replaced by oats in the following spring 2013 because of failed wintering of the rye. Permanent grassland had no management practices during the two study years.

The sandy Toholampi site had a total of 16 experimental plots under four crop rotations, of which four plots with two different rotations were selected for this study. The selected rotations included organic cereal cultivation (two plots) that received manure (cattle slurry) and conventional farming (two plots) that received mineral fertilization. These 4-year crop rotations had been carried on since 1997 (organic farming with manure) and 2001 (conventional farming with mineral fertilization). Plots treated with manure were 
sown with a mixture of oat and vetch for green fodder in the first spring of this study, and during the second spring the plots were sown with barley together with a mixture of grass and clover seed. Cattle slurry was applied at the rate of c. $50 \mathrm{t} \mathrm{ha}^{-1}$ in the beginning of the summer in both study years. In the first study year plots were ploughed before, and on the second year at the same time as the slurry application was performed. No herbicides were applied on these plots. Plots with the mineral fertilization were sown with oats in 2012 and barley in 2013. Except for fertilization and herbicide spreading, all other cultivation practices on the plots were performed at the same time for all four plots (Table S1).

\subsection{Climatic conditions and discharges from the study sites}

The monitoring period of DOC in discharge started on $19^{\text {th }}$ of March 2012 and ended on $7^{\text {th }}$ of March 2014, thus comprising two study years. At Yöni site the discharge from the experimental plots was collected as total discharge including both surface runoff and artificial subsurface drainage. At Kotkanoja and Toholampi sites the discharge was collected as separated between surface runoff and artificial subsurface drainage. Both of the study years were divided into four seasons using temperature criteria that define the seasons by the daily mean temperatures. Thus, the spring begins when the mean daily temperature rises above $0^{\circ} \mathrm{C}$, and spring turns to summer when the mean daily temperature stays above $10^{\circ} \mathrm{C}$. The autumn begins when the mean daily temperature stays below $10^{\circ} \mathrm{C}$, and the winter begins when the mean daily temperature drops below $0^{\circ} \mathrm{C}$.

Both study years were fairly similar in seasonal temperatures except for winter. The mean daily winter temperature in Toholampi was ca. $5^{\circ} \mathrm{C}$ warmer and precipitation was $150 \mathrm{~mm}$ higher in the second study year compared to the first study year. The annual sum of precipitation both at Jokioinen research station and Toholampi experimental site, were slightly higher for the first study year (699 and $740 \mathrm{~mm}$, respectively), compared to the second study year (533 and $714 \mathrm{~mm}$, respectively). Although temperature and precipitation were fairly similar between Toholampi site and the two sites at Jokioinen research station (Kotkanoja and Yöni), the seasonal distribution of discharge varied substantially. At Kotkanoja and Yöni sites, $50 \%$ or more of the annual discharge came in the autumn on both study years (Fig. 1). The mean spring discharge from Toholampi site, in turn, accounted for nearly $50 \%$ of the annual volume, but in the second study year as much as $65 \%$ of the discharge volume occurred in the winter due to high precipitation and a relatively warm winter (Fig. 2).

From Kotkanoja experimental plots the subsurface drainage, when expressed as a proportion of the total discharge (71-82\%), was clearly higher compared to surface runoff (18-29\%) for both study years and management practices, although no-till plots had slightly higher proportion of surface runoff compared to 
ploughed plots. In Toholampi site, the trend was similar for the first study year as the percentage of subsurface drainage from the total discharge was $85-92 \%$ for both management practices. However, in the second study year the mean percentage of surface runoff was high being $58 \%$ from the plots treated with manure and $40 \%$ with mineral fertilization.

\subsection{Sampling and laboratory analysis}

Surface runoff and subsurface drainage water samples at Kotkanoja and Toholampi sites were collected using a flow-based sampling system, in which automatic water collection was done with a simple tip-over system of known volume (a tipping bucket). The flow between two samplings was calculated based on the number of tip-overs, and the flow-weighted samples for analysis were compiled from each turn. The total number of water samples for each four plots at Kotkanoja site was 71 for surface runoff and 69 for subsurface drainage water over the entire study. The corresponding numbers of water samples for Toholampi site during the two-year study were 34 for surface runoff and 84 for subsurface drainage water. The total discharge at Yöni site was directed into collection wells from which it was pumped away, and during the uplift, a flow-proportional sample was collected. The flow was calculated according to the electricity consumption of the pumps. The discharge data is shown in the Figures 1 and 2. A total of 193 water samples were taken from each six plots at Yöni over the two year period of the study.

After collection, the samples were centrifuged to remove mineral particles and stored frozen at $-20^{\circ} \mathrm{C}$ before analysis. The melted samples were filtered through Whatman GF/F filters $(\varnothing 0.7 \mu \mathrm{m})$ before DOC and total dissolved nitrogen (TDN) measurement with high-temperature catalytic oxidation (HTCO) using Shimadzu TOC-V CPH analyzer. Inorganic nitrogen forms of nitrate $\left(\mathrm{NO}_{3}-\mathrm{N}\right)$ and ammonia $\left(\mathrm{NH}_{4}-\mathrm{N}\right)$ were measured with Lachat Quick Chem autoanalyzer after filtration of the samples as described by Turtola and Paajanen (1995). DOC and DON concentrations were calculated as the difference between measured total and inorganic concentrations. Seasonal and annual loads were calculated by multiplying each measured concentration from a plot with the volume of discharge and summing them up. Mean concentrations are calculated as flow-weight bases.

\subsection{Bioavailability of DOC in Kotkanoja}

In the autumn 2013 the surface runoff and subsurface drainage water collected separately from the two replicated ploughed and no-till plots of the Kotkanoja site were used in a 2-month incubation experiment with typical bacteria communities collected from the Baltic Sea seawater to estimate the biodegradability of DOC, i.e. labile DOC (LDOC) in the surface runoff and subsurface drainage water that flows to 
agriculturally loaded rivers. Water samples were collected separately over 17 hour period starting from $23^{\text {rd }}$ of October 2013 at 3 pm with the flow-weighted sampling system. Samples were filtered through three connected cartridge filters (1. Sartopure PP2 MidiCap, nominal cut-off $3 \mu \mathrm{m}, 2$. Sartoclean GF Sterile MidiCap $3+0.8 \mu \mathrm{m}$, and 3. Sartobran 300 Sterile Capsule $0.45+0.2 \mu \mathrm{m}$ by Sartorius Stedim Biotech) to remove particulate matter and most of the bacterial cells and bacterivores. Each water sample was treated with synthetic sea salt (Tropic Marine Sea Salt, Dr. Biener GmbH, Wartenberg, Germany) prior to the incubation to increase the salinity to $6.0 \%$ (salinity of the coastal bacterial inoculum) and sampled for $\mathrm{NO}_{3}$ $\mathrm{N}, \mathrm{NH}_{4}-\mathrm{N}$ and $\mathrm{PO}_{4}-\mathrm{P}$ measurements. Five liters of each filtered water sample was inoculated with natural bacterial communities from the Baltic Sea. Seawater for the inocula was collected from the open sea surface water $8 \mathrm{~km}$ from the shore off Helsinki (Gulf of Finland, Baltic Sea). The seawater samples were filtered through Sartoclean GF Sterile MidiCap $3+0.8 \mu \mathrm{m}$ filters (Sartorius Stedim Biotech), and concentrated 50 -fold with tangential flow filtration $(100 \mathrm{kD})$ to minimize the addition of seawater DOM into the Kotkanoja water samples. The concentrated inocula were then divided into the surface runoff and subsurface drainage water samples ( $1 \mathrm{ml}$ of inoculum per 1 liter of Kotkanoja water), in order to obtain the final bacterial concentration at approximately $5 \%$ of the original seawater.

Each surface runoff and subsurface drainage water samples from four different experimental plots were divided into two subsamples: one remained without any nutrient additions (LDOC), and the other one had phosphate $\left(\mathrm{PO}_{4}-\mathrm{P}\right)$ solution added to reach $2 \mu \mathrm{mol} \mathrm{I}^{-1}$ (LDOP) to ensure the $\mathrm{P}$ sufficiency in these subsamples during the incubation. The original $\mathrm{N}$ concentration was high enough $\left(\mathrm{NO}_{3}-\mathrm{N}\right.$ concentration of 0.4-24 $\mathrm{mg}^{-1}$ in the surface runoff and subsurface drainage water), and thus, no $\mathrm{N}$ limitation was expected during the incubation and no $\mathrm{N}$ addition was needed. After nutrient and bacterial additions, each subsample was siphoned into acid-washed $500-1000 \mathrm{ml}$ capacity Duran-bottles and $100 \mathrm{ml}$ capacity oxygen bottles for the 60-day incubation. Each water sample was divided into three bottles for LDOC measurement, and samples were taken after $0,14,30$ and 60 days during the incubation. Similarly, for the LDOP measurement the water samples were divided into three bottles but samples (DOC, TDP and $\mathrm{PO}_{4}-\mathrm{P}$ ) were taken only at the beginning and at the end, thus after 0 and $60 \mathrm{~d}$, of the incubation. The samples were incubated in a dark room at $15^{\circ} \mathrm{C}$ temperature.

At each sampling, the subsamples for DOC, TDP and $\mathrm{PO}_{4}-\mathrm{P}$ were filtered through $0.22 \mu \mathrm{m}$ syringe filters (Millipore). The samples were acidified with $\mathrm{HCl}$ to $\mathrm{pH} 2.5$ and frozen at $-20^{\circ} \mathrm{C}$ until $\mathrm{DOC}$ measurement with high-temperature catalytic oxidation (HTCO) by Shimadzu TOC-V CPH analyzer. The concentration of labile DOC was calculated from the decrease of DOC concentration during the incubation. Inorganic nutrients were measured according to Grasshoff et al. (1983). Nutrient concentrations at the beginning and at the end of the bioavailability experiment in Kotkanoja are presented in Table 2. 


\subsection{Data analyses and statistics}

To test whether the DOC concentrations varied according to the agricultural management practices, the seasonal concentrations were tested using paired sample T-test (95\% confidence intervals) separately for each site (hypothesis 2). Correlations between soil carbon content and DOC load (hypothesis 1 ) in addition to correlations between DOC and DON were tested with Pearson correlation ( $99 \%$ confidence intervals) by combining data from all three sites. Statistical analyses were performed with IBM SPSS Statistics version 22.

\section{Results}

\subsection{DOC concentrations and annual loads}

During the two-year surveillance, annual DOC load varied between $25-52 \mathrm{~kg} \mathrm{ha}^{-1}$ for cultivated plots and 44$59 \mathrm{~kg} \mathrm{ha}^{-1}$ for the permanent grassland plots. However, variation between the study years was large, and differences between the cultivation practices were not clear (Fig. 3). Thus, under these conditions manure application did not increase the DOC load compared to mineral fertilizers. Similarly, the no-till treatment did not change the total DOC load compared to ploughing. However, the DOC load from permanent grassland at the clayey Yöni site was significantly higher than the load from the cultivated plots treated with mineral fertilization $(p=0.026)$ and manure $(p=0.034)$ at the same site.

The DOC concentrations varied between the years and did not differ between surface runoff and subsurface drainage water (Table 3). The annual flow-weighted DOC concentrations in surface runoff from all four plots of the sandy Toholampi field were higher for the first study year as the mean ranged from 13.5 to $19.9 \mathrm{mg} \mathrm{l}^{-1}$ when compared to the concentrations of 6.3-8.6 $\mathrm{mg} \mathrm{l}^{-1}$ in the second study year. Two high volume surface runoff events (Fig. 2) and an unusual distribution of discharge characterized by high winter runoff (Table 4) contributed to much lower DOC concentrations found for the second study year. The subsurface drainage water mean DOC concentrations in Toholampi samples were similar for both study years, and they ranged from 12.4 to $17.5 \mathrm{mg} \mathrm{l}^{-1}$ for all four plots.

The mean annual flow-weighted DOC concentrations from four plots of Kotkanoja clayey soil varied from 10.5 to $11.5 \mathrm{mg} \mathrm{l}^{-1}$ in the first study year, and from 9.7 to $10.6 \mathrm{mg} \mathrm{l}^{-1}$ in the second study year, and these values did not differ between surface runoff and subsurface drainage. However, the concentrations varied slightly more in the subsurface drainage water than in the surface runoff. The DOC concentrations in the 
total discharge from the Yöni site varied from 9.6 to $16.7 \mathrm{mg} \mathrm{l}^{-1}$ in the first study year, and from 8.7 to 13.5 $\mathrm{mg}^{-1}$ in the second year for all six experimental plots.

Similarly, management-induced differences were not detected during the two study years for flowweighted DOC concentrations from cultivated fields. The annual mean DOC concentrations of surface runoff from the no-till plots of the clayey Kotkanoja $\left(13.4 \mathrm{mg} \mathrm{l}^{-1}\right)$ were slightly higher compared to ploughed plots $\left(11.0 \mathrm{mg} \mathrm{l}^{-1}\right)$ on the first study year, but no such difference was observed during the second study year. In Yöni field, the DOC concentrations of the total discharge water from permanent grassland plots were higher compared to plots managed with manure or mineral fertilizer $(p=0.027$ and $p=0.023$, respectively). However, no differences between the concentrations of manure and mineral fertilizer managements were found.

The distribution of DOC load followed well the seasonal distribution of discharge (Table 4). More than $60 \%$ of the DOC load from Kotkanoja and Yöni was discharged with the autumn high flow. In contrast, at Toholampi site, the loads were high during high discharges in the first spring 2012-13 and the second winter 2013-14. Over the entire two-year study period, most of the discharge and DOC load (68-86\%) from Kotkanoja clay soil was carried by the subsurface drainage water. At Toholampi sandy soil the two years varied between the discharge routes. In the first study year (2012-13), there was only a small amount of surface runoff, and $90 \%$ of the annual discharge and $85-94 \%$ of the DOC load came via subsurface drainage flow. However, during the second study year $40 \%$ to $60 \%$ of the annual discharge came during the spring and winter. During these high discharge events, the DOC concentrations in the surface runoff at the Toholampi site were relatively low (5.5-9.5 $\left.\mathrm{mg} \mathrm{l}^{-1}\right)$ and $24-43 \%$ of the total annual DOC load was exported by surface runoff.

The mean DOC load exported by surface runoff from the no-till plots of the Kotkanoja site were $8.4 \mathrm{~kg} \mathrm{ha}^{-1}$ for the first study year and $7.7 \mathrm{~kg} \mathrm{ha}^{-1}$ for the second study year. Both of these were higher than the corresponding values of 5.4 and $4.6 \mathrm{~kg} \mathrm{ha}^{-1}$ for ploughed plots on the first and second year, respectively. However, the export by subsurface drainage from the no-till plots was 16.6 and $20.3 \mathrm{~kg} \mathrm{ha}^{-1}$ on the first and second study year, respectively, which was slightly lower compared to corresponding values of ploughed plots (19.4 and $23.5 \mathrm{~kg} \mathrm{ha}^{-1}$ ). Therefore, the total DOC load was not affected by differences in tillage method at this site.

The lowest annual DOC load was observed at Kotkanoja with the lowest soil C\% in the uppermost soil layer and a high percentage of subsurface drainage flow, whereas the highest annual DOC load was observed at Yöni site from permanent grassland with the highest C\% at the soil surface $(0-5 \mathrm{~cm})($ Table 1$)$. The DOC loss 
increased with increasing topsoil C content (Fig. 4. Pearson correlation $0.643, p<0.01$ ). We found similar, but weaker relationship between the DOC load and the C\% in the $20-40 \mathrm{~cm}$ soil layer (Pearson correlation $0.487, p<0.01)$. However, if the two years are studied separately, the dependence of total DOC load on soil C\% was not significant for the second study year.

\subsection{DON concentrations and annual loads}

During the two study years the annual DON load from the experimental fields varied between 0.8-3.2 $\mathrm{kg} \mathrm{ha}^{-}$

${ }^{1}$. The mean annual flow-weighted DON concentrations for the first and second study years varied between 0.7-0.8 $\mathrm{mg} \mathrm{l}^{-1}$ at Kotkanoja, 0.5-0.9 $\mathrm{mg} \mathrm{l}^{-1}$ at Yöni and 0.3-1.0 $\mathrm{mg} \mathrm{l}^{-1}$ at Toholampi sites (Table 3). No clear effects of agricultural cultivation practices on the DON concentrations or loads were detected, and the total DON loads were found very similar for all experimental plots (Fig. 5).

A more clear relationship between DOC and DON concentrations was detected in the surface runoff than subsurface drainage. DOC:DON relation in total discharge was not affected by different cultivation practices, but it was higher in sandy soil at Toholampi compared to clayey sites (Table 3). No clear trend between dissolved inorganic $\mathrm{N}$ and DON was found. The proportion of DON from the TDN load varied, as it was much higher for permanent grassland plots at $63 \%$ than for cultivated plots, in which the means ranged from 9 to $28 \%$ during the two study years. Further, the annual percentage of DON in TDN in the surface runoff (25-63\%) was higher than in the subsurface drainage water (7-24\%), but most of the DON load (5193\%) was still exported by subsurface drainage. The percentage of DON in the surface runoff was higher for no-till plots compared to ploughed plots at Kotkanoja site, while it was similar between manure and mineral fertilizer applications at Toholampi site.

\subsection{The share of labile DOC}

The percentage of LDOC estimated from the decrease in DOC concentration during 60-day incubation varied between $7 \%$ and $23 \%$ in nutrient replenished conditions (Table 5). The mean concentration of LDOC was $2.3 \mathrm{mg} \mathrm{l}^{-1}$ (ranged from 1.4 to $4.1 \mathrm{mg} \mathrm{l}^{-1}$ ). Without $\mathrm{PO}_{4}-\mathrm{P}$ addition the mean LDOC concentration was 1.5 $\mathrm{mg} \mathrm{l}^{-1}$ (ranged from 0.8 to $2.7 \mathrm{mg} \mathrm{l}^{-1}$ ) and thus, the higher available phosphorus concentration in the experiment increased the LDOC concentrations by a mean of 50\%. DOC in surface runoff water from ploughed plots was more bioavailable compared to the no-till plots. In subsurface drainage water, the variation in the LDOC proportion out of the total DOC was large and no differences were detected between the land-use types. 


\section{Discussion}

\subsection{DOC loads from differently managed agricultural soils}

A high proportion of agricultural land in catchment areas in central Europe has been reported to clearly increase the annual discharge-weighted DOC concentrations in rivers $\left(6.2-7.1 \mathrm{mg} \mathrm{Cl}^{-1}\right)$ when compared to forested catchments (1.3-3.8 $\mathrm{mg} \mathrm{Cl}^{-1}$ ) (Graeber et al., 2012). Wilson and Xenopoulos (2008), on the other hand, did not find agricultural land use to be a good predictor for DOC export. In northern Europe, the relative abundance of peatlands and wetlands in the catchment are associated with elevated DOC concentrations in river water (Laudon et al., 2004; Kortelainen et al., 2006). The present study found that the DOC concentrations measured in discharge water of cultivated fields were higher than those reported by Graeber et al. (2012), but fell in the same range of concentrations $\left(5-21 \mathrm{mg} \mathrm{l}^{-1}\right)$ measured from large rivers in Finland (Mattsson et al., 2009).

Our results on mean annual DOC load from cultivated fields $\left(25-52 \mathrm{~kg} \mathrm{ha}^{-1}\right)$ are in agreement with the findings obtained by Räike et al. (2012), who reported a mean DOC export of $38 \mathrm{~kg} \mathrm{ha}^{-1}$ from agricultural land. In general, the DOC loads of less than $50 \mathrm{~kg} \mathrm{ha}^{-1}$ from agricultural soil in the present study, are in the same magnitude as those measured in upland forest dominated mineral soil catchments in Finland (Rantakari et al., 2010). Higher DOC load from permanent grassland compared to cultivated soil with mineral fertilization and manure application is most likely due to higher $\mathrm{C}$ content in the surface soil on the studied grassland (Table 1). The effect of agricultural land-use on DOC concentrations is most likely masked by the relatively high SOM content in the boreal zone (Autio et al., 2016).

The proportion of organic soil or peatland on the catchment scale correlates positively with DOC concentration and load (Kortelainen et al., 1997; Laudon et al., 2004; Mattsson et al., 2005; Räike et al., 2012; Autio et al. 2015), and loads as high as $80-140 \mathrm{~kg} \mathrm{ha}^{-1}$ have been reported for peatland dominated (>50\%) catchments (Rantakari et al., 2010). The surface soil OC concentration of mineral soil however is much lower compared to organic and peat soils. Nevertheless, even with the small range of surface soil OC\% in the experimental sites used in this study, we still found a positive relationship between DOC load and surface soil OC\%. Our results indicate, that in agricultural fields the soil OC\% of the top layer can be used as a rough indicator for estimating the DOC load. As the higher OC content in the surface soil appears to increase the DOC load, we suggest that agricultural cultivation practices that build up OC in topsoil gradually increase the DOC load from agricultural fields and vice versa. However, the timing of the discharge can significantly affect the amount of annual load. 
In organic farming, manure applications together with forage legumes in the crop rotation are expected to increase surface soil OC\% (Gattinger et al., 2012). However, such an increase was not detected in our experimental sites and this may explain why no marked differences in DOC concentrations and loads between the mineral fertilization and manure treatments were detected in our study. The experimental plots of both treatments had similar crop rotations, and the greatest difference in organic matter input between the two treatments is the manure addition. Thus, in soils where the organic matter content is relatively high, the manure addition may not lead to significantly higher OC\% compared to mineral fertilization with similar soils. For the no-till plots, the accumulation of $\mathrm{OC}$ in the uppermost surface soil was evident and similar findings have been reported e.g. by Alvarez et al. (1995). The higher DOC load via surface runoff from the no-till plots is thus in agreement with their higher surface soil OC\%. However, in our results, the surface runoff DOC concentrations from no-till plots were higher only in the first study year when compared with the ploughed soil plots. This highlights the role of the discharge in DOC load formation. Thus, the increased surface runoff volumes rather than DOC concentrations of no-till plots, compared to those of the ploughed plots, was behind the larger DOC load via surface runoff.

Royer et al. (2007) found the mean DOC concentration at $6.5 \mathrm{mg} \mathrm{l}^{-1}$ in subsurface drainage water to be lower than the concentrations in surface runoff $\left(12.7 \mathrm{mg} \mathrm{l}^{-1}\right)$ in fields under corn (Zea mays L.) and forage cropping systems. When water percolation through the soil profile allows more contacts between solutes and soil, DOC sorption onto soil particles is enhanced (McDowell and Wood, 1984; Hinton et al., 1998; Hope, 1994). Our results did not show differences in the DOC concentrations between the surface runoff and subsurface drainage water, which suggests that during the high flow events that dominate the DOC export, the water transport is relatively fast, and significant sorption does not take place. Preferential flow (e.g. via cracks and large pores in the soil) may facilitate fast migration of DOC from the surface soils into the subsurface drainage system.

The strong positive relationship between DOC load and discharge causes the DOC load to be highly variable over time (Royer and David, 2005; Dalzell et al., 2007; Ruark et al., 2009). Low quantities of DOC export are expected during low-flow conditions that occur usually in winter season under snow cover, and higher exports during intensive rain events in the autumn and during snowmelt in the spring (Ågren et al., 2007). Our results also showed that weather conditions have a great effect on the timing of the DOC load entering the streams. Precipitation in Finland in the autumn leads to high discharges due to cool air temperatures and low transpiration after harvest. Indeed, at Yöni and Kotkanoja sites the discharge volume was highest and the proportion of the DOC load was largest during the autumn. On the other hand, half of the annual discharge and leaching from headwater catchments in Finland may occur in spring when snow is melting, 
although the spring period accounts only $10-15 \%$ of the entire year (Kortelainen et al., 1997). The spring flood that follows the thaw has been reported to deliver $50-68 \%$ of the yearly TOC for forested boreal catchments in northern Sweden (Laudon et al., 2004). In our study, the highest DOC loads at the Toholampi site occurred with high discharge in the spring and winter. The spring time discharge is greatly affected by the weather conditions in winter season: after a typical cold winter, snowmelt in the spring cause high surface runoff. During cold winters, the discharge that originates from fresh snowfall or mid-winter snowmelt does not come into direct contact with surface soil because of the remaining frost. This results in low DOC concentrations in surface runoff. Relatively warm winter temperatures without soil frost and snow cover, in turn, may lead to high discharge and loads during the winter as well. If warm air temperatures and rain events occur more frequently during winter in the future, it is likely to shift the timing of discharge and DOC load into a more winter dominated direction.

\subsection{Agricultural soil as a source of DON load}

The measured DON concentrations in discharge water from agricultural fields were in line with the concentrations in Finnish rivers (0.21-0.91 $\mathrm{mg} \mathrm{l}^{-1}$ ) that were reported by Mattsson et al. (2005). The DON load from agricultural soil in this study also falls within the same range as reported by Kortelainen et al. (2006) for annual DON loads $\left(0.2-2.1 \mathrm{~kg} \mathrm{ha}^{-1}\right)$ from natural unmanaged forested catchments. On the catchment level, agricultural fields have been found to increase DON export (Jordan et al., 1997; Mattsson et al., 2009), and the increase has been suggested to originate from the application of organic fertilizers and intensive farming (Mattsson et al., 2005). However, the DON loads from different experimental plots in our study were fairly similar and did not show any evidence of increased DON load due to manure treatment. Further, despite different crops and fertilization (organic vs. mineral) the range of DON loads was only slightly larger compared to forested unmanaged catchments (Kortelainen el al., 2006). The higher DON concentrations in river waters from agricultural catchments may result from biological processes and conversion of inorganic nitrogen into DON in streams, rather than being transported as DON from external sources, such as agricultural soil (Chapman et al., 2001).

Strong positive relationship between DOC and DON has been reported in stream waters of upland and forested areas (Harriman et al., 1998; Goodale et al., 2001) and in large Finnish rivers (Mattsson et al., 2005). Similarly, the DOC and DON correlated positively in our study especially in the surface runoff, which suggests that the DON load exported in the surface runoff could be roughly estimated by using information on DOC load. However, here the subsurface drainage accounted for more than half of the total discharge, and the relationship between DON and DOC in the subsurface drainage water was not as clear; thus the total DON load estimated from the DOC load may be a fairly inaccurate value for subsurface drainage. 
Mattsson et al. (2005) found that the proportion of organic $N$ was approximately $64 \%$ of the TDN exported through Finnish main rivers. As estimated from a diverse set of agricultural systems, Van Kessel et al. (2009) reported that approximately one-third of the TDN lost with discharge water was DON. The ratio of DON:TDN in a catchment depends considerably on the dissolved inorganic $\mathrm{N}$ concentrations that increase within increasing proportion of agricultural land in the catchment (Pellerin et al., 2006). Our results showed that the proportion of DON in discharge from cultivated soil was in maximum one-third of TDN, and these results are supported by Kessel et al. (2009). The proportion of DON in discharge from permanent grassland was two-thirds of TDN, which was the same magnitude as reported by Mattsson et al. (2005) for large rivers with a high proportion of forest in the catchments.

\subsection{Bioavailability of DOC}

Land use intensity has been found to affect the composition of DOC in headwater streams (Graeber et al., 2015; Heinz et al., 2015). Previously Royer and David (2005) measured DOC in stream water that drained from intensively farmed areas in Illinois and found a mean of $18 \%$ of DOC as being bioavailable in a 30-day incubation period. Heinz et al. (2015) found DOM in agricultural ditches to be mainly complex and aromatic material with a low C:N ratio and more microbial processed, compared to subsurface drainage water from forested areas. However, Autio et al. (2015) reported that the percentage of bioavailable DOC was independent of land use and soil type. Our results from two-month incubation of discharge waters showed a fairly large variation in the proportion of LDOC but the results are of the same order of magnitude as previously reported for Boreal rivers (Autio et al., 2015; Lapierre \& del Giorgio, 2014). All these reported results suggest that less than $25 \%$ of terrestrial DOC in waters is degraded biologically without UV-light. About $10 \%$ of the DOC exported from the fields is likely to be buried in sediment due to flocculation in brackish water with low salinities (Asmala et al., 2013) implying that photochemical oxidation is an important loss term for terrestrial DOC in fresh waters in the arctic (Aarnos et al., 2012).

Interestingly, the proportion of LDOC appeared larger in the surface runoff of ploughed plots than the corresponding value of no-till plots. The higher microbial activity in the surface soil under no-till plots (Doran, 1980; Kandeler et al., 1999) may result the DOC being processed more towards aromatic substances than in ploughed soil, which could result in lower lability values. The proportion of LDOC in subsurface drainage water in both ploughed and no-till plots were similar which suggests that the processes affecting bioavailability of DOC are fairly similar below the surface of no-till and ploughed soils. Further, the incubation that occurred in the phosphorus-replenished conditions increased the proportion of LDOC, which suggests that the microbial growth in discharge water may be limited by phosphorus 
availability. According to Marschner and Kalbitz (2003) nutrient addition may stimulate DOM degradation during incubation. We measured the bioavailability of DOC only once during the two years study period, and could not see very clear differences between the land-use types.

\section{Conclusions}

This study shows that DOC loads from mineral soils under agriculture are comparable to those of boreal forests with similar soil types. Moreover, the DON loads from differently managed agricultural soils are fairly similar and only slightly larger than those reported for forested catchments. The DOC loads were found to be mostly discharge dependent, and thus, varied considerably between the seasons and between the years. In the changing climate conditions in high latitudes, the change in timing and amount of precipitation are likely to increase the discharge, and thus, increasing DOC loads during winter seasons will be most likely observed in the future. More research is therefore needed to understand the reactions and role of DOM of agricultural origin in marine systems over time.

Consistent with our first hypothesis, we found that the higher OC content in the soil surface appears to increase the DOC load, which suggests that agricultural practices that lead to OC enrichment in topsoil may increase the DOC load into surface waters. Thus, in addition to the discharge volume, the carbon content in mineral soils regulate the $\mathrm{DOC}$ load in the discharge that enters to the receiving waters, and the OC\% in surface soil can be used to estimate approximately the DOC load from cultivated mineral soils. The twomonth incubation experiment showed that the availability of the DOC was low, and the proportion of labile DOC in surface runoff was slightly larger when soil was ploughed compared to no-till. However, contrary to our second hypothesis, the studied agricultural practices did not affect the DOC and DON loads and our results did not show clear differences in the concentrations between surface runoff and subsurface drainage flow.

\section{Acknowledgements}

This study was a part of the MULTIDOM project that is funded by the Helsinki University Centre for environment HENVI. It has also been supported by Institute of Natural Resources Institute Finland (Luke) and the Marine Research Centre of the Finnish Environment Institute (SYKE) in the study design, the data collection and the laboratory analyses. The authors thank the Maj \& Tor Nessling Foundation and the Marjatta \& Eino Kolli Foundation for their financial support for this work. We also thank the University of Helsinki for the facilities for interpretation of data and writing the article. 
Appendix 1. Supplementary data 